\title{
Consumption of Purple Soy Tofu in Improving Hyperglycemia Condition and Nutritional Intake to Type-2 Diabetes Mellitus Respondents
}

\author{
Sri N. Amrizal ${ }^{\#}$, Fransisca R. Z ${ }^{\#}$, Suliantari ${ }^{\#}$, Ekowati Chasanah",

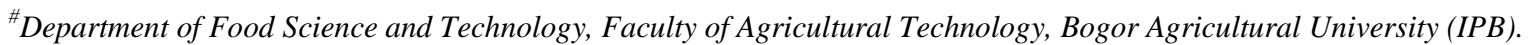 \\ Email: srinovalinaa@gmail.com, since@apps.ipb.ac.id, suli_tari@yahoo.com \\ ${ }^{*}$ Research and Development Center for Marine and Fisheries Product Processing and Biotechnology \\ Email: ekowatichasanah@gmail.com
}

\begin{abstract}
Diabetes Mellitus (DM) is a chronic metabolic disorder disease, caused by the insufficiency and ineffectiveness of insulin utilizing and then result in insulin resistance. This study purposed to identify the effect of purple tofu intervention, which made from black soybean in improving hyperglycemic conditions and nutritional intake of type 2 diabetes mellitus (T2DM). An intervention of purple soy tofu was performed for 28 days with 20 subjects, divided into two groups (control and treated group), and selected purposively. Eighty-five grams of tofu was served with additional vegetable broth in the intervention group, while people in the control group did not accept any treatment. There was a significant improvement in hyperglycemia and nutritional intake of diabetics (p < 0.05 ) at the end of the intervention. Analysis of fasting blood glucose levels of respondents to purple tofu decreased from 224.7 \pm 92.45 to $170.2 \pm 68.15$; plasma insulin levels increased from $0.29 \pm 0.08$ to $0.39 \pm 0.11$. Our findings suggested that purple tofu interventions improved the condition of hyperglycemia in T2DM respondents through the elevating of plasma insulin levels.
\end{abstract}

Keywords - T2DM; hyperglycemia; purple tofu; optional diabetic diet; blood glucose; insulin.

\section{INTRODUCTION}

Diabetes mellitus includes as a chronical disease, characterized by an exceeding threshold of glucose condition (hyperglycemia) [1]. The hyperglycemia tends to lead the synthesis of Reactithe ve Oxygen Species (ROS) that causes stress oxidative [2]. Excessive stress oxidative triggers an immune reaction such as inflammation [3]. ROS or free radicals attack the DNA of the pancreatic cell and causes $\beta$ cell dysfunction, decreases the number of $\beta$-cells, and exacerbates the insulin resistance [4].

The prevalence of diabetics in 2015 reached 415 million people and was estimated to increase to 642 million people in 2040. Indonesia was the seventh ranking of diabetes mellitus in the world in 2015, with 10 million people of diabetics [5]. Diabetes mellitus may not be overcome, but it may be controlled by reducing the risk factors. Improving the dietary pattern and increasing physical activities are ways to decline obesity rates. Light exercise for 30 minutes, 4-5 times a week repairs signaling of insulin [6]. The healthy diet is performed by consuming plant-based foods, which contain a high nutritional value, fiber, bioactive components, and low glycemic index (GI) [7].
Tofu is well known as a soybean processed product in Indonesia. Tofu has high digestibility around 95\%, and suitable to be consumed for all ages [8]. In addition, tofu is a satisfying food and is chosen as substitute food to regulate body weight or to reduce obesity [9]. Tofu contains high protein and essential amino acids, low saturated fat, high unsaturated fatty acids, cholesterol-free, a source of B vitamins, minerals, is flavones, phenolic components, and thiol (SH) [10], [11]. Commonly, tofu is made from yellow soybean, but purple tofu, which made from black soybean variety is rarely produced. Exploration of black soybean processed product such as tofu will raise the spirit of farmers to optimize the production of such variety.

Purple tofu is a potential of food to repair diabetic metabolic syndrome conditions. Black soybeans contain bioactive components of isoflavones such as genistein $(0.65$ $\mathrm{mg} / \mathrm{g})$, daidzein $(3.67 \mathrm{mg} / \mathrm{g})$, and anthocyanins $(222.49 \mathrm{mg} / \mathrm{g})$ [12]. Meanwhile, purple soy tofu contains daidzein isoflavones $(19.72 \mathrm{mg} / 100 \mathrm{~g})$, and genistein $(18.32 \mathrm{mg} / 100 \mathrm{~g})$ [13]. The number of bioactive components in black soybeans is higher than yellow soybeans. Scientific data which concern about the advantages of purple tofu consumption for the diabetic patient have not been available. Therefore, the purpose of the present study was to determine the effect of purple to consumption which is produced from black 
soybean in improving hyperglycemic conditions and to increase the nutritional intake of T2DM patients.

\section{MATERIAL AND METHOD}

\section{A. Design, Place, and Time of Study}

The study was an experimental research design (QuasiExperimental Study), conducted from October 2014 to December 2015 at dr. Katie's clinic Dramaga Bogor, at Biochemical Laboratory, Department of Food Science and Technology, and Animal Disease Laboratory, Faculty of Veterinary Medicine, Bogor Agricultural Institute.

\section{B. Materials and Tools}

Purple tofu (Cikuray black soybean varieties, from a local plantation in Lampung), blood samples of respondents (before and after intervention), mouse monoclonal insulin antibody (Abcam, UK), mouse IgG antibody, HRP (Genetex, USA), TMB/3,3', 5,5'-tetramethylbenzidine liquid substrate (Sigma Aldrich, USA). The equipment used for blood analysis were centrifuge, ELISA reader, micropipette, microplate 96 well, and glucometer (Accu-check performance, USA).

\section{Steps of Study}

The study consisted of several steps. First was the respondent selection and ethical clearance submission. The respondents used met the inclusion (T2DM, 50-65 years of ages, blood glucose levels $>200 \mathrm{mg} / \mathrm{dL}$, and received recommendations from the physicians) and exclusion (pregnancy, gangrene, and smoking). The estimation of the number of respondents was determined by different test formula [14]. Ten respondents were fixed to each number of groups (intervention and control) and added with $10 \%$ dropout possibility. Respondents study were local citizens of Dramaga District, Bogor District. Ethical clearance was approved by The Ethical Commission of Institute of Research and Community Service of the Catholic University of Atmajaya Jakarta with number 576/III/LPPMPM.10.05/07/2014. The second step was to prepared purple tofu [15]; seeds were sorted, washed, soaked for 12 hours with the ratio (water 3: seeds 1), and drained from water residue. Seeds were ground with water at $80^{\circ}-85^{\circ} \mathrm{C}(8: 1)$. Black soybeans porridge was boiled at $105^{\circ} \mathrm{C}$ for ten minutes, filtered with 100 mesh, and soybean milk resulted. Milk was coagulated with $\mathrm{CaSO}_{4}$ at $70^{\circ}-85^{\circ} \mathrm{C}$, mixed slowly until it separated from the way. Curds were pressed for 15-20 min to create a compact of tofu texture. The tofu was cut and soaked in cold water at $5^{\circ} \mathrm{C}$, boiled, and ready to serve. The third, the intervention of the subject. The intervention was performed for 28 days. Eighty-five grams of tofu was served with additional vegetable broth. Our team supervised the respondents to consume purple tofu for three days continuously, to ensure that tofu was eaten appropriately. Evaluation of purple tofu acceptance and impact of the intervention, on respondent health were performed by discussion and visual observation every seven days for four weeks. Analysis of Proximate [16] analyzed the purple tofu. Analysis of daily consumption pattern (food recall 24 hours method by using NutriSurvey Method) was obtained by interviewing of respondent every week. Data were analyzed by using bivariate analysis, to observe the difference of macro nutritional intake means between before and after the intervention. Fourth, blood collection. Blood was taken twice during the study, on day- 0 when socialization of activity (before the intervention), and on day-28 after the intervention. Syringe took eight milliliters of blood and transferred into vacutainer, which contained EDTA as anticoagulant. Blood analysis consisted of fasting blood glucose [17] and insulin plasma levels. Fasting blood glucose was performed before and after tofu intervention. Respondents had to do fasting for 8 hours before the blood sample taken [18]. Blood was obtained from the fingertips and affixed to the glucometer strip. Measurements were performed in the morning between $7 \mathrm{am}$, and $9 \mathrm{am}$. A total of $100 \mu \mathrm{L}$ plasma was diluted with carbonate/bicarbonate buffer and transferred into microplate 96 wells, incubated at $4{ }^{\circ} \mathrm{C}$ for 24 hours. The supernatant was discarded and washed with 250 $\mu \mathrm{L} /$ well PBST solution for three times, $100 \mu \mathrm{L} /$ well skim milk $5 \%$ was added and incubated at $37^{\circ} \mathrm{C}$ for an hour, discarded supernatant and washed with PBST three times. Mouse monoclonal insulin antibody was added as much as $100 \mu \mathrm{L} /$ well, incubated at $37^{\circ} \mathrm{C}$ for an hour. The supernatant was discarded and washed with PBST three times. Antimouse anti-mouse polyclonal antibodies were added 100 $\mu \mathrm{L} /$ well, incubated at $37^{\circ} \mathrm{C}$ for an hour. The supernatant was discarded and washed with PBST three times. The TMB substrate was added with $50 \mu \mathrm{L} /$ well in the dark condition and incubated at $37^{\circ} \mathrm{C}$ for $15 \mathrm{~min}$. Furthermore, $50 \mu \mathrm{L} /$ well $\mathrm{H} 2 \mathrm{SO} 41 \mathrm{~N}$ was added as stop solution. The color intensity was read using a micro plate reader at $450 \mathrm{~nm}$ wavelength [19].

\section{Data Analysis}

Data were analyzed by SPSS ver.22 using Mann Whitney test with $95 \%$ confidence interval to investigate the difference between fasting blood glucose level and plasma insulin level on control respondent and purple tofu intervention before and after intervention.

\section{RESULTS AND DISCUSSION}

\section{A. Chemical Composition of Tofu Purple}

Evaluation of purple tofu nutrients included proximate analysis. Table 1 showed the chemical composition of purple tofu consists of water content, protein, fat, dietary fiber, ash, and Calcium. Purple tofu has high protein content in sufficient amount for diabetic's respondent. Protein in soybean improves the lipid profile in hyperglycemic conditions of people with T2DM [20]. Furthermore, high dietary fiber in purple tofu plays a role as a sufficient food as a fiber source which is needed by diabetic patients.

TABLE I

The Chemical Composition of PuRple Soy Tofu

\begin{tabular}{|l|l|}
\hline \multicolumn{1}{|c|}{ Parameter } & \multicolumn{1}{c|}{ Amount (db) } \\
\hline Water content & 5.24 \\
\hline Protein & 53.92 \\
\hline Fat & 26.33 \\
\hline Soluble dietary fiber & 4.33 \\
\hline Ash & 4.66 \\
\hline $\mathrm{Ca}$ & 0.78 \\
\hline $\mathrm{P}$ & 0.71 \\
\hline
\end{tabular}


Dietary fiber repairs blood glucose levels, by delaying postprandial glucose absorption and gastric emptying time [21]. The limited content of carbohydrates and higher content of protein makes soy a good candidate for the management of glycemic response in diabetes and insulin resistance patients and more in general in metabolic diseases [22]. Soybean consumption improves blood lipid levels, regulates insulin under normal circumstances, and promotes weight loss [23]. Several physiological effects and clinical benefits of soy fiber are by lowering cholesterol level in patients with hypercholesterolemia, improving glucose tolerance, increasing insulin tolerance on hyperlipidemia and diabetic patients, and increasing stool volume to accelerate food transit times [24].

The purple tofu also contains high dietary fiber (Table 5), wherein the consumption of dietary fiber is needed for diabetics. Dietary fiber can improve blood glucose levels, as it slows postprandial glucose absorption and gastric emptying time [21]. Soy is a high-fiber diet that is ideal for diabetic patients diet [25]. Eating soy may improve blood lipid levels and regulate insulin under normal circumstances [26].

The physiological effects and clinical benefits of soy fiber are by lowering cholesterol in patients with hypercholesterolemia, improving glucose tolerance and insulin response in hyperlipidemia and diabetic patients, and increasing the volume of the stools to speed up food transit times [27], [28].

\section{B. Characteristics of Respondents}

Respondents involved in this research were people who live in one village near the campus of Bogor Agricultural Institute Dramaga. The rationale for the selection of respondents was that of having adjacent residence, activity, the economic level was almost the same, so it was expected that the respondents have eating habits and nutritional conditions were not much different.

Two groups of respondents; purple soy tofu intervention and control group, the intervention group consisted of two males and eight females, whereas the control group consisted of three males and seven females. Based on body mass index (BMI) category, the number of normal respondents in the intervention group was five respondents, pre-obese were two respondents, and three others were obese. In the control group, normal BMI were two respondents, four respondents were pre-obese, and two respondents were obese. BMI category determination was based on less $(\leq 18.5$ $\mathrm{kg} / \mathrm{m} 2)$, normal (18.5-24.9 kg/m2), pre-obesity ( $\geq 25 \mathrm{~kg} / \mathrm{m} 2)$, and obesity $(\geq 30 \mathrm{~kg} / \mathrm{m} 2)$ [29]. Most of the respondents in this study were women in both groups, with overweight and pre-obese. The result of the study showed the prevalence of women with diabetes mellitus was higher than men because women's activities were less than men. Therefore, blood glucose is less used to generate energy. Also, overweight (obese) respondents risk twice in developing diabetes mellitus than normal weight respondents [30].
TABLE II

DATA ON ANTHROPOMETRIC AND BODY MASS INDEX (BMI) OF INTERVENTION GROUP

\begin{tabular}{|c|c|c|c|c|}
\hline Respondents & $\begin{array}{c}\text { Weight } \\
(\mathrm{Kg})\end{array}$ & $\begin{array}{c}\text { Height } \\
(\mathrm{cm})\end{array}$ & BMI & $\begin{array}{c}\text { BMI } \\
\text { Category }\end{array}$ \\
\hline Male & & & & \\
\hline 1 & 55 & 159.5 & 21,62 & Normal \\
\hline 2 & 72.5 & 160.7 & 28.07 & Pre Obese \\
\hline Female & & & & \\
\hline 3 & 64.5 & 160.7 & 31.32 & Obese \\
\hline 4 & 68.5 & 154.5 & 28.70 & Pre Obese \\
\hline 5 & 51 & 146.0 & 23.93 & Normal \\
\hline 6 & 48.5 & 143.1 & 23.68 & Normal \\
\hline 7 & 45.5 & 152.1 & 19.67 & Normal \\
\hline 8 & 54.5 & 160.8 & 21.08 & Normal \\
\hline 9 & 84 & 158.0 & 33.65 & Obese \\
\hline 10 & 51.5 & 153.0 & 22.00 & Normal \\
\hline
\end{tabular}

*BMI was in accordance based on WHO (2006)0: Less $\left(<18,5 \mathrm{~kg} / \mathrm{m}^{2}\right)$, normal $\left(18,5-24.9 \mathrm{~kg} / \mathrm{m}^{2}\right)$, Pre Obese $\left(>25 \mathrm{~kg} / \mathrm{m}^{2}\right)$, Obese $\left(>30 \mathrm{~kg} / \mathrm{m}^{2}\right)$

\section{Nutritional Intake of Respondents}

The result of the nutritional intake of respondents with type 2 diabetes mellitus in the intervention and control group (by ignoring the consumption of purple tofu) was presented in Table 2. By consuming $85 \mathrm{~g} /$ day of purple tofu contributed protein, fat, and fiber $(6.66 \mathrm{~g} / \mathrm{day} ; 2.14 \mathrm{~g} /$ day; $4.72 \mathrm{~g} /$ day, respectively) and calories (83.47 Kcal/day) in intervention group, or equivalent with $17 \%$ protein, $6.13 \%$ fat, and $58.70 \%$ fiber, and $6.62 \%$ energy. A detail calculation of nutritional intake contributing by purple tofu was showed in Table 3.

TABLE III

THE COMPARISON OF DAILY NUTRITIONAL INTAKE BETWEEN INTERVENTION AND CONTROL GROUP

\begin{tabular}{|l|l|l|}
\hline \multicolumn{1}{|c|}{ Macronutrients } & \multicolumn{1}{c|}{$\begin{array}{c}\text { Intervention } \\
\text { group }\end{array}$} & Control group \\
\hline Protein intake (g/day) & \multicolumn{1}{|c|}{} & \\
\hline Day-1 & $38.57 \pm 17.06$ & $38.39 \pm 15.00$ \\
\hline Day-7 & $39.42 \pm 6.18$ & $39.61 \pm 9.97$ \\
\hline Day-14 & $36.04 \pm 14.60$ & $41.77 \pm 8.55$ \\
\hline Day-21 & $50.41 \pm 26.94$ & $43.62 \pm 6.75$ \\
\hline Day-28 & $34.55 \pm 9.69$ & $37.39 \pm 6.79$ \\
\hline Average & $39.79 \pm 6.52$ & $40.15 \pm 2.53$ \\
\hline From purple tofu & 6.66 & \\
\hline Total of protein intake & 46.45 & 40.15 \\
\hline Fat intake (g/day) & & \\
\hline Day ke-1 & $40.92 \pm 24.30$ & $31.89 \pm 23.39$ \\
\hline Day ke-7 & $38.34 \pm 13.83$ & $53.12 \pm 19.35$ \\
\hline Day ke-14 & $39.62 \pm 26.94$ & $53.82 \pm 28.62$ \\
\hline Day ke-21 & $30.09 \pm 18.34$ & $59.05 \pm 28.26$ \\
\hline Day ke-28 & $25.68 \pm 13.13$ & $51.96 \pm 18.26$ \\
\hline Average & $34.93 \pm 6.68$ & $49.96 \pm 10.46$ \\
\hline From purple tofu & 2.14 & - \\
\hline Total of fat intake & 37.07 & 49.96 \\
\hline Carbohydrate intake (g/day) & \\
\hline Day-1 & $222.6 \pm 112.40$ & $171.57 \pm 93.53$ \\
\hline Day-7 & $244.36 \pm 116.34$ & $209.88 \pm 139.44$ \\
\hline Day-14 & $181.75 \pm 88.86$ & $208.24 \pm 97.30$ \\
\hline
\end{tabular}




\begin{tabular}{|l|l|l|}
\hline Day-21 & $166.46 \pm 119.04$ & $212.82 \pm 81.27$ \\
\hline Day-28 & $191.29 \pm 120.59$ & $226.24 \pm 47.77$ \\
\hline Average & $201.292 \pm 31.63$ & $205.75 \pm 20.37$ \\
\hline From purple tofu & - & - \\
\hline $\begin{array}{l}\text { Total of carbohydrate } \\
\text { intake }\end{array}$ & 201.29 & 205.75 \\
\hline Fibers intake (g/day) & & \\
\hline Day-1 & $9.38 \pm 4.20$ & $6.05 \pm 4.09$ \\
\hline Day-7 & $9.17 \pm 5.25$ & $8.4 \pm 4.42$ \\
\hline Day-14 & $7.6 \pm 4.71$ & $9.7 \pm 5.80$ \\
\hline Day-21 & $7.13 \pm 3.51$ & $11.42 \pm 5.50$ \\
\hline Day-28 & $7.01 \pm 3.01$ & $12.84 \pm 6.19$ \\
\hline Average & $8.05 \pm 1.13$ & $9.68 \pm 2.63$ \\
\hline From purple tofu & 4.72 & - \\
\hline Total of fibers & 12.77 & 9.68 \\
\hline Energy (Kcal/day) & & \\
\hline Day-1 & $1372.85 \pm 536.84$ & $1140.03 \pm 517.26$ \\
\hline Day-7 & $1464 \pm 417.31$ & $2739.12 \pm 651.38$ \\
\hline Day-14 & $1214.95 \pm 299.89$ & $1525.05 \pm 568.38$ \\
\hline Day-21 & $1120.47 \pm 546.81$ & $1628.67 \pm 539.75$ \\
\hline Day-28 & $1127.3 \pm 533.81$ & $1565.92 \pm 302.01$ \\
\hline Average & $1259.57 \pm 153.09$ & $1719.4 \pm 601.09$ \\
\hline From purple tofu & 83.47 & - \\
\hline Total of energy & 1343.04 & 1719.4 \\
\hline
\end{tabular}

The daily nutritional intake of protein and fiber between intervention and control groups was almost same, but the number of protein and fiber intake in the intervention group was higher than the control group after purple tofu administration. Table 8 explained that the daily intake of protein and fiber was $46.45 \mathrm{~g} /$ day and $12.27 \mathrm{~g} /$ day. Fats and carbohydrates were $37.07 \mathrm{~g} /$ day and $201.29 \mathrm{~g} /$ day in the intervention group. Fat and carbohydrate intakes were 49.96 $\mathrm{g} /$ day and $205.75 \mathrm{~g} /$ day, respectively in the control group.

Dietary recommendation for people with diabetes is healthy foods with high fiber and low glycemic index (GI) and avoiding of fried foods [31]. Protein and fiber are the important components for DM patients, foods with high protein such as purple tofu can suppress the hunger [32]. Also, the fiber is significant for the body and is needed for DM patients, acts to slow the process of gastric emptying and the absorption of blood glucose by small intestine [33]. The requirement of fiber intake for adults is about $15 \%$ per day obtained from food.

The higher amount of protein in the intervention group was due to the high intake of protein by adding purple tofu in diet regularly every day for 28 days. The purple tofu contains $6.66 \%$ protein of $85 \mathrm{~g}$ in a dish during the intervention. Meanwhile, the lower protein intake was showed in the control group, the absence of purple tofu contributed to elevating the protein intake. The amount of fat consumed for 28 days in the control group was higher than the intervention group. The different treatments between two different groups affected the intake of fat significantly. Low fat intake is expected to improve the condition of dyslipidemia as one of the triggers to worsen diabetes.

The lower carbohydrate intake in the intervention group than in the control group indicated that respondents in intervention group began to understand how to manage diabetes mellitus by improving the quality of diet, by reducing the carbohydrate intake such as rice, bread and others with high GI content. Eating foods with a high number of GI leads to increase blood glucose level rapidly [34]. Blood glucose control plays a role in people with diabetes mellitus regarding GI content of food [35]. Besides, the lower intake of carbohydrates in the intervention group was affected by the level of satiety of tofu routinely consumed in the intervention group.

\section{Fasting Blood Glucose}

Fasting blood glucose is an early indicator of diabetes mellitus detection. Cut off of normal fasting blood glucose levels is $110 \mathrm{mg} / \mathrm{dL}$ [36]. Purple soy tofu is an alternative food for people with diabetes mellitus. Fig. 2 demonstrated that routinely consuming purple soy tofu in 28 days significantly decreased fasting blood glucose levels of the intervention group $(\mathrm{P}<0.05)$.

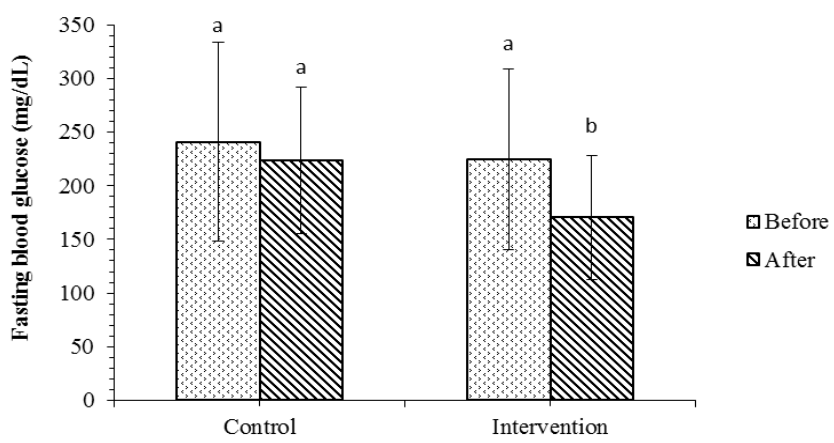

Fig. 1 Fasting blood glucose level of T2DM

Decreasing of fasting blood glucose levels also occurred in the control group, but statistically insignificant $(\mathrm{P}>0.05)$. The change in control and intervention group on 28 days did not show a significant decrease $(\mathrm{P}>0.05)$. Tofu is a highly nutritious food with high fibers, with low glycemic index and high digestibility rate and quite fulfilling. Tofu suppresses and controls the elevation of blood glucose levels, and indirectly improves insulin sensitivity in the diabetic patient. Also, bioactive components in tofu (anthocyanin and is flavones) play a role in regulating homeostasis of blood glucose and insulin in the blood [37].

\section{E. Plasma Insulin Levels}

Insulin is a hormone secreted by $\beta$ pancreatic cells, to control blood glucose levels in normal condition, by facilitating glucose uptake and regulating carbohydrate, fat, and protein metabolism. Insulin levels increase when blood glucose elevation occurs in plasma [38]. The quantity of available insulin on a T2DM patient is not proportional to blood glucose quantity [39]. Fig. 1 showed a significant increase in insulin levels $(\mathrm{P}<0.05)$ in the intervention group. Insulin levels tended to increase in the control group, but it was not statistically significant $(\mathrm{P}>0.05)$. The changes of insulin level in the intervention group after 28 days showed a significant difference $(\mathrm{P}<0.05)$ than in control group.

Fig. 2 presented the condition of insulin deficiency in two groups. Increased insulin in the intervention group showed that the consumption of purple tofu leads higher insulin secretion of T2DM patients. High isoflavones content in purple tofu plays a role in increasing insulin secretion. In previous studies [40] indicated isoflavones in Tempe increased insulin secretion. Insulin level was also elevated in 
the control group, although it was not statistically significant $(\mathrm{P}>0.05)$. The increase was the result of socialization and education regarding the management of diabetes mellitus to patients, by applying a healthy diet and increase physical activities.

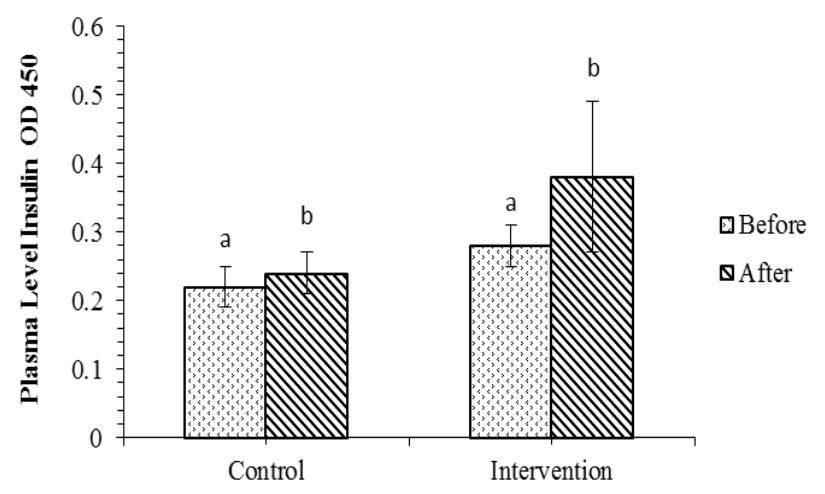

Fig. 2 Plasma insulin level of T2DM

\section{F. Amino Acid Contents}

TABLE IV

AMINo ACIDS COMPONENTS IN PURPLE TOFU AND BLACK SOYBEANS BASED ON WHO

\begin{tabular}{|l|l|l|}
\hline \multicolumn{1}{|c|}{$\begin{array}{c}\text { Type of amino } \\
\text { acid }\end{array}$} & \multicolumn{2}{c|}{ Amino acid (mg/g) } \\
\cline { 2 - 3 } Aspartic & $1.86 \pm 0.21$ & \multicolumn{1}{c|}{ Dry weight (DW) } \\
\hline Glutamate & $2.20 \pm 1.35$ & $8.3 \pm 3.11$ \\
\hline Serine & $0.81 \pm 0.01$ & $2.66 \pm 0.07$ \\
\hline Histidine & $0.36 \pm 0.01$ & $1.24 \pm 0.01$ \\
\hline Gysin & $0.65 \pm 0.01$ & $2.16 \pm 0.07$ \\
\hline Tryptophan & - & - \\
\hline Threonine & $0.56 \pm 0.01$ & $1.84 \pm 0.03$ \\
\hline Arginine & $1.21 \pm 0.15$ & $3.53 \pm 0.19$ \\
\hline Alanin & $0.83 \pm 0.91$ & $2.77 \pm 0.02$ \\
\hline Tyrosine & $0.62 \pm 0.01$ & $2.05 \pm 0.01$ \\
\hline Methionine & $0.19 \pm 0.02$ & $0.69 \pm 0.01$ \\
\hline Valine & $0.87 \pm 0.01$ & $2.9 \pm 0.01$ \\
\hline Phenylalanine & $1.00 \pm 0.01$ & $3.35 \pm 0.01$ \\
\hline Isoleusin & $0.85 \pm 0.01$ & $2.84 \pm 0.04$ \\
\hline Leusin & $1.35 \pm 0.01$ & $4.53 \pm 0.01$ \\
\hline Lysine & $0.99 \pm 0.09$ & $2.93 \pm 0.84$ \\
\hline SAA & - & - \\
\hline AAA & - & - \\
\hline
\end{tabular}

Amino acids are proteins, and there are two types of nonessential amino acids that can be produced by the body, such as alanine, serine, glycine, glutamate, serine, and aspartate. While essential amino acids are amino acids that cannot be made by the body, obtained from food intakes, such as histidine, cysteine, methionine, isoleucine, lysine, leucine, methionine, phenylalanine, threonine, tryptophan, and valine.
Consumption of purple tofu contributes to the availability of essential amino acids that are very important for the body.

The purple tofu contained 15 amino acids (Table 4) consisting of eight essential amino acids. Glutamate was the highest number of amino acids compared to other amino acids. Glutamate is an amino acid that plays an important role in forming food flavors in tofu [12]. Also, arginine, serine, and lysine play an important role for the body by preventing inflammation by increasing the synthesis of GSH so that GSH content in cell elevates, followed by a decrease in inflammatory factors such as IL-1, IL-6, and TNF- $\alpha$. Increased glutathione also enhances IL-2, so that $\mathrm{T}$ cells are activated to improve cellular and humoral immunity [18]. Purple tofu also contains bioactive components such as flavonoids that also act as antioxidants such as isoflavone and anthocyanin (Table 7).

TABLE V

BIOACTIVE COMPONENTS IN PURPLE TOFU

\begin{tabular}{|l|l|}
\hline \multicolumn{1}{|c|}{ Type of bioactive components } & Amount (mg/100g) \\
\hline Total flavonoid & $42.02 *$ \\
\hline Isoflavon : & \\
\hline Daidzein & $19.72 * *$ \\
\hline Genistein & $18.32 * *$ \\
\hline Total anthocyanine & $1.80 * * *$ \\
\hline
\end{tabular}

Note: $*=$ Meriyanti (2015); $* *=$ Zuhri (2015); $* * *=$ Zakaria et al . (2016)

Table 5 showed that purple tofu contained a total of 42.02 $\mathrm{mg} / 100 \mathrm{~g}$ of flavonoid, Daidzen was $19.72 \mathrm{mg} / 100 \mathrm{~g}$, and genistein was $18.32 \mathrm{mg} / 100 \mathrm{~g}$. Also, there was $1.80 \mathrm{mg} / 100$ $\mathrm{g}$ of anthocyanin in purple tofu [41, 13, 15]. The processing of soybeans into tofu reduces the number of active components such as isoflavones and anthocyanins. Consumption of normal daily intake of active components such as isoflavones to improve health according to FSC [42] is as much as $30 \mathrm{mg}$.

\section{CONCLUSION}

Purple tofu which is made from black soybeans is a potential food to improve hyperglycemia conditions. It can be determined by the decrease of fasting blood glucose levels and elevation of plasma insulin levels. Moreover, soy tofu consumption for 28 days showed an increase in nutritional intake such as protein and fibers in T2DM patients. We recommended purple tofu as an alternative food on the diabetic diet.

\section{ACKNOWLEDGMENTS}

The authors are grateful to the Ministry of Research, Technology and Higher Education of the Republic of Indonesia and Kreasi Inovasi Prosana Ltd, Jakarta, for financial support towards this research. As corresponding author in this study is Prof. Fransiska R. Zakaria.

\section{REFERENCE}

[1] A. Ullah, A. Khan, I. Khan, "Review diabetes mellitus and oxidative stress-A concise Review," Saudi Pharmaceutical Journal, vol 24, pp 547-553, Sept. 2016

[2] L. J. Yan, "Review article pathogenesis of chronic hyperglycemia: From reductive stress to oxidative stress," Journal of Diabetes Research, vol. 2014, pp 11 pages. 2014. http://dx.doi.org/10.1155/2014/137919 
[3] S. Tangvarasittichai, "Oxidative stress, insulin resistance, dyslipidemia and type 2 diabetes mellitus," World J Diabetes, vol. 15, pp. 456-480, April. 2015.

[4] S. K. Saha, S. B. Lee, J. Won, H. Y. Choi, K. Kim, G. M. Yang, A. A. Dayem and S. G. Cho, "Review: Correlation between oxidative stress, nutrition, and cancer initiation," Int. J. Mol. Sci., vol.18, pp. 130, July. 2017; doi:10.3390/ijms18071544

[5] (2015) International Diabetes Federation. International diabetes federation diabetes atlas. [Online]. Available: http://www.idf.org/

[6] R. Marinho, L. P. De-Moura, B.A. Rodrigues, L.S.S. Pauli, A. S. R. De-Silva, E. C. C. Ropelle, C. T. De-Souza, D. E. C Cintra, E. R. Ropelle, and J. R. Pauli, "Effects of different intensities of physical exercise on insulin sensitivity and protein kinase B/Akt activity in skeletal musclw of obese mice," Enstein, vol 12, pp 82-89. 2014

[7] F. Rungkat-Zakaria, "Vegetable food, intact and functional as healthy diet composer." Scientific Oration, Institute of Bogor Agricultur, Bogor. 2015.

[8] N. Triandita, F. Rungkat-Zakaria, E. Prangdimurti, and N.E. Putri "Improvement in antioxidant status of type-2 diabetes mellitus patients using dietary fiber rich-tofu from black soybean," J Teknol Ind Pangan, vol. 27, pp. 123-130. 2016.

[9] D. A. Williamson, P. J. Geiselman, J. Lovejoy, F. Greenway, J. Volaufova, C. K. Martin, C. Arnett and L. Ortego, "Effects of consuming mycoprotein, tofu or chicken upon subsequent eating behaviour, hunger and safety," Appetite, vol. 46, pp. 41-48. 2006.

[10] V. Poysa and L. Woodrow, "Stability of soybean seed composition and its effect on soymilk and tofu yield and quality," Food Research International, vol. 35, pp. 337-345. 2002.

[11] S. O. Shokunbi, O. Babajide, D. O. Otaigbe and G.O. Tayo, "Effect of coagulants on the yield nutrient and antinutrient composition of tofu," Archives of Applied Science Research, vol. 3, pp. 522-527. 2011.

[12] Nurrahman, "Evaluation of nutritional composition and antioxydant compounds in black soybeans and yellow soybeans," Jurnal Aplikasi Teknologi Pangan, vol. 4, pp. 89-93. 2015.

[13] M.A.M. Zuhri, "Effects of black soybean tofu intervention to glicaemic control of group in diabetics mellitus," B.Sc Theses. Bogor Agriculture University, Bogor. 2015.

[14] S. Lameshow, J. R. Hosmer, J. Klar and S. K. Lwanga, "Sample range in Health Research," Book, Gajah Mada University, Yogyakarta. 1997.

[15] F. Zakaria-Rungkat, D. P. R. Firdaus, and N. D. Yuliana, "Black soybean tofu consumption for improving SGOT/SGPT and antioxidant activity of type-2 diabetic respondent plasma," J Pangan. vol. 2, pp. 95-104. 2016.

[16] (2005) AOAC. Association of analitycal communities. official methods of analysis of the association of official analytical chemistry. 16th Edn., AOAC International, Washington, USA. Pages: 1141.

[17] R. Irwanto, F. Zakaria-Rungkat, D. R. Adawiyah, "Physiological roles of black soybean milk enriched with microencapsulated crude palm oil in diabetes type-2 patients," J Teknol Ind Pangan, vol. 27, pp. 1-9. 2016

[18] R. F. Hasrini, F. R. Zakaria, D. R. Adawiyah, I. Herawati, Suparto, "Antidiabetic and immunomodulatory potential of purple soymilk enriched with crude palm oil microcapsule in type-2 diabetes mellitus respondents," Mal J Nutr., vol. 23, pp. 461 - 471, 2017.

[19] F. Zakaria-Rungkat, I. N. Azni, E. Syamsir, K. M. Amalia and C. Yamani, "Infuence of oxygenated water consumption in chronicobstructive pulmonary disease (COPD) patients," J Tekno Ind Pangan., vol. 25, pp. 31-38. 2014.

[20] D. Y. Kwon, J. W. Daily $3^{\text {rd }}$, H. J. Kim, S. Park, "Antidiabetic effects of fermented soybean products on type 2 diabetes," Nutrition Research, pp. 1-13, Jan. 2010. https://doi.org/10.1016/j.nutres.2009.11.004

[21] P. S. Thondre, "Food base ingredients to modulate blood glucose," $J$. Advances in Food and Nutrition Research, vol. 70, pp. 181-227. 2013.

[22] G. Rizzo, and L. Baroni, "Review: soy, soy foods and their role in vegetarian diets," Nutrients, vol.10, pp. 43, 2018; doi:10.3390/nu10010043
[23] D. D. Ramdath, E. M. T. Padhi, S. Sarfaraz, S. Renwick and A. M Duncan, "Review: beyond the cholesterol-lowering effect of soy protein: a review of the effects of dietary soy and its constituents on risk factors for cardiovascular disease," Nutrients, vol. 9, pp. 324, 2017; doi:10.3390/nu9040324

[24] (2009) S. Koswara. Technology of Soybeans Processing. [Online]. Available: www.ebookpangan.com.

[25] C. Retnaningsih, Z. Noor, and Y. Marsono "Hypoglicaemic characteristic in food with high protein soybeans in diabetic model; alloxan induction." Jurnal Teknol. Ind Pangan. vol. 12, pp. 141-146. 2010.

[26] C. Ascencio, N. Torres, F. Isoard-Acosta F, JF GomezPerez, R Hernandez-Pando , and AR Tovar, "Soy protein affects serum insulin and hepatic srebp-1 mrna and reduces fatty liver in rats," Journal of Nutrition, vol. 134, pp. 522-529. 2004.

[27] M. Chandalia, A. Garg, D. Lutjohann, K. Von-Bergmann, SM. Grundy, and L.J. Brinkley, "Beneficial effects of high dietary fiber intake in patients with type 2 diabetes mellitus, "New England Journal of Medicine, 342, 1392-1398. 2001.

[28] E.A. Meiflorisa, Tejasari, and Giyarto, " Glycemic index of nugget from tempeh and pecay, "J. Agriteknol, vol 11, pp. 35-44. 2017.

[29] A. L. Klatsky, J. Zhang, N. Udaltsova, Y. L. H. Nicole Tran, "Body mass index and mortality in a very large cohort: is it really healthier to be overweight?" Perm J., vol. 21, pp. 16-142, 2017. E-pub: 06/29/2017 https://doi.org/10.7812/TPP/16-142

[30] S. Akter, M. M. Rahman, Abe S and P. Sultana, "Prevalence of diabetes and prediabetes and their risk factors among Bangladesh adults: a nationwide survey," Bull World Health Organ, vol. 92, pp. 204-213A. 2014.

[31] R. Bilous and R. Donelly. Handbook: diabetes. Book, Bumi Medika, Jakarta. 2015

[32] D. Muchtadi. Soybeans as A Health Component. Book, Alfabeta, Bandung. 2010.

[33] G. Riccardi, A. A. Rivellese, and R. Giacco. "Role of glycemic index and glycemic load in the healthy state in prediabetes and in diabetes," Am J Clin Nurt., vol. 87, pp. 269S-274S. 2008.

[34] T. Yalçın, A. Al, and N. Rakıcıoğlu, "The effects of meal glycemic load on blood glucose levels of adults with different body mass indexes," Indian J Endocrinol Metab., vol. 21, pp. 71-75, Jan-Feb 2017. doi: $10.4103 / 2230-8210.195995$

[35] C. O. Eleazu, "The concept of low glycemic index and glycemic load foods as panacea for type 2 diabetes mellitus; prospects, challenges and solutions," Afr Health Sci., vol. 16, pp. 468-479. Jun 2016 doi: 10.4314/ahs.v16i2.15

[36] Z. Ghazanfari, A. A. Haghdoost, S. M. Alizadeh, J. Atapour, and F. Zolala, "A comparison of HbAlc and fasting blood sugar tests in general population," Int J Prev Med., vol. 1, pp. 187-194. Summer 2010.

[37] D. Y. Kwon, J. W. Daily, H. Kim and S. Jet Park, "Antidiabetic effects of fermented soybean products on type 2 diabetes," Nutr Res., vol. 30, pp. 1-13. 2010.

[38] P. V. Röder, B. Wu, Y. Liu, and W. Han, "Pancreatic regulation of glucose homeostasis," Exp Mol Med., vol. 48, pp. e219. Mar 2016. doi: $10.1038 / \mathrm{emm} .2016 .6$

[39] J. J. Marín-Peñalver, I. Martín-Timón, C. Sevillano-Collantes, and F J. del Cañizo-Gómez, Update on the treatment of type 2 diabetes mellitus," World J Diabetes., vol. 15, pp. 354-395. Sept. 2016 Sep doi: $10.4239 /$ wjd.v7.i17.354

[40] NE. Putri, F. Rungkat-Zakaria, E. Prangdimurti, and N. Triandita, "Effect of dietary fiber rich-tofu from black soybean on bloods glucose and inflammatory syndrome of type 2 diabetes mellitus subjects, "J Teknol. Ind Pangan, vol 27, pp. 131-139. 2016.

[41] Meriyanti D. 2015. Control of Malondialdehyde (MDA) Levels of Diabetes Mellitus Patients through Intervention to Know Black Soybeans. [Essay]. Bogor (ID): Bogor Agricultural University

[42] [FSC] Food Safety Commission. 2006. Fundamental consepts in the safety assessment of foods containing soy isoflavones for the purpose of specified health use. Japan: Novel Foods Expert Committee. 